\title{
Cooperative Model Type STAD and Its Effect on Student Learning Outcomes at Sustainability Accounting Courses Asniati Bahari ${ }^{1 *}$, Elvira Luthan ${ }^{2}$, Winda Azmi ${ }^{3}$, Alya Ledias Anshar ${ }^{4}$
}

\author{
${ }^{1}$ Universitas Andalas, Padang \\ ${ }^{2}$ Universitas Andalas, Padang \\ ${ }^{3}$ Universitas Andalas, Padang \\ ${ }^{4}$ Universiti Teknologi Malaysia, Johor Bahru, Malaysia \\ *Corresponding Author Email: asniati.bahari@gmail.com
}

\begin{abstract}
This study aims to determine the Student Teams Achievement Division (STAD) cooperative learning model's effect on student learning outcomes in sustainability accounting courses. This research is a quasi-experimental study involving two groups of students at Andalas University with a total sample of 47 students. The first group of students was not involved with the STAD model, while the second group, students were directed by using the STAD method. By using questionnaires, students were asked to assess their achievements related to (1) attitude and character, (2) improvement in presentation and discussion performance, (3) their experience of making group assignments, and (4) their experience in the implementation of peer reviews. The findings of the study indicate that the application of the STAD type cooperative method can increase student grades. In this study, comments and input were also obtained for improving future learning methods for Sustainability Accounting courses.
\end{abstract}

Keywords: STAD Type Cooperative Method, Learning Outcomes, Sustainability Accounting, Peer Review

\section{INTRODUCTION}

The higher education curriculum was developed into a Semester Learning Plan (called in Indonesia as $R P S)$. In the implementation of lectures, lecturers must compile a Lecture Program Unit (called in Indonesia as $S A P$ ) based on the RPS of the course. With the development and implementation of the curriculum, it is expected that competencies in the graduation competency standards can be achieved. Learning process planning is compiled for each subject and presented in RPS or other terms determined and developed by the lecturer independently or together in the expertise group of a field of science and technology in the study program. Other terms referred to include the Semester Learning Activity Program Plan (called in Indonesia as RPKPS), Lecture Guidelines, or Study Contracts [1].

RPS is used as a reference by lecturers and students in the learning process/lecture activities in one semester. Article 12 Paragraph (1) of Kemenristekdikti

[2] states that the learning process is based on the RPS prepared for each course. Furthermore, Article 12 Paragraph (3) states that the RPS contains at least eight points, including learning methods. In the learning process, educators must use the right method or model for the courses being taught. Besides, using new media will make it easier for educators to teach the material presented. One of the courses that must be developed is the Sustainability Accounting course because seeing that previous students' learning outcomes have not been satisfactory.

Accounting for Sustainability is an optional course in the accounting study program offered in the sixth semester. This course is one of the fields of management accounting. Sustainable Accounting as a particular course in management accounting. The Management Accounting course is a prerequisite for taking this course. This course discusses the concepts, methods, and techniques of sustainability accounting and the principles and standards of sustainability reporting. Sustainability accounting is a new field in management accounting developed for the contribution of sustainable development, which is defined as development that meets current needs without compromising future generations' ability to meet their own needs [3].

Previously, the Sustainability Accounting course used the discussion method on learning, but the measurement of its performance was not optimal. Therefore, an appropriate method is needed to redevelop learning methods. The model to be developed is the Student Teams Achievement Division (STAD) type, cooperative model. This model is a series of learning activities carried out by students in specific groups to achieve the learning objectives that have been formulated. Cooperative learning type STAD could improve student learning and increase mutual help in social behavior [4]. 
Researchers chose the STAD type cooperative

learning model for the Sustainability Accounting course because this model is a type of model that is quite effective and can teach students to socialize more with peers and train students to issue creative ideas conveyed to group members can also arouse. The enthusiasm of students when they see the great theme cognitively, affective, or psychomotor. As explained by Isjoni [4], the STAD type of cooperative learning model is a type of cooperative that emphasizes the existence of activities and interactions between students to motivate and help each other and master the subject matter in order to achieve maximum achievement. A suitable type STAD is learning for grouping mixed abilities that involve team recognition and group responsibility for individual member learning [5].

Also, the reason the researcher chose the STAD type cooperative learning model was because it had advantages that were very influential for student learning. The advantages of the STAD type suitable method are as follow [6], :

1) Show that there is competition for each group to become a champion. It means that each group is taught to be more active and strive in group work to create solidarity to achieve a victory.

2) Very helpful for students in overcoming learning difficulties, mistakes, and misconceptions that have been wrong so far,

3) Students are more courageous in presenting arguments during the discussion.

4) STAD helps create interactive learning, fun, and motivates students to participate actively in learning. Thus, education should be able to condition and provide encouragement to optimize and generate student potential, foster activity, and creativity (creativity) to guarantee dynamics in the learning process. Therefore, the purpose of this study was to see whether there was an effect of the STAD cooperative model on the learning outcomes of UNAND students in the Sustainable Accounting course.

\section{LITERATURE REVIEW}

\subsection{Learning Outcomes}

In simple terms, learning outcomes are abilities that children get after going through learning activities. Learning outcomes are some experiences obtained by students which include the cognitive, affective and psychomotor domains; meaning that learning is not only mastery of subject theory concepts, but also mastery of habits, perceptions, pleasures, interests, social adaptations, types of skills, ideas, desires, and expectations [7]. Furthermore, a person's learning outcomes can be seen from changes in their behavior, from initially not knowing to know, from not being able to become able, from being unable to be able, and from being unskilled to being skilled [8]. Such changes can be said as a form of individual learning outcomes. So, it can be concluded that learning outcomes are changes in someone who is gained through experience from the learning process.

\subsection{Sustainability Accounting}

The term "Sustainability Accounting" is not a standard term in accounting. Accounting for Sustainability consists of two words, namely "accounting" and "sustainability". According to the AICPA, accounting is the expertise to record, classify, and summarize appropriately and are expressed in money, transactions that are at least financial, and interpret them [9]. So, accounting plays a role in providing information for the wearer. Meanwhile, Sustainability means being continuous with long-term / future-oriented thinking. Sustainability accounting is an accounting system that focuses on financial, social, and environmental transactions or events so that the reporting output contains financial, social, and environmental information [10].

Accounting for Sustainability is an optional course in the accounting study program offered in the sixth semester. This course is one of the fields of management accounting. Sustainable Accounting as a particular course in management accounting. The Management Accounting course is a prerequisite for taking this course. The learning approach uses Student Center Learning (SCL), where the lecturer acts as a facilitator. The learning methods developed were presentations, discussions, and group assignments.

This course discusses the concepts, methods, and techniques of sustainability accounting and the principles and standards of sustainability reporting. Sustainability accounting is a new field in management accounting developed for the contribution of sustainable development, which is defined as development that meets current needs without compromising future generations' ability to meet their own needs [3]. Sustainable development includes three aspects, namely, economic, environmental, and social. These three aspects are known as the triple bottom line. The output of sustainability accounting is a sustainability report. The international standard used to prepare sustainability reports is the Global Reporting Initiative (GRI) Guideline Generation4 (G4). However, along with science development, since 2018, the guideline in preparing sustainability reports is the GRI Standards (GRI Standards).

The main objective of this course is that students are expected to understand and identify the concept of sustainable development, system concepts, methods, and techniques of sustainability accounting, and the principles and standards of sustainability reporting. Students can also evaluate company sustainability reports following sustainability reporting standards.

\subsection{Cooperative Model Type STAD}

Cooperative learning encourages students to interact actively and positively in groups, allowing the exchange of ideas in a comfortable atmosphere following the philosophy of constructivism [11]. The purpose of this cooperative learning method is that students learn together and help each other in completing tasks with an emphasis on mutual support between group members because the learning success of students depends on the success of the group. The cooperative learning method 
has recently become a concern and even recommended by education experts because it is alleged to improve the quality of students' process and learning outcomes. There are suggests two reasons to implement cooperative learning [11], namely as follows:

1) Based on the results of several studies conducted by educational experts, it is evident that using cooperative learning methods can improve student learning achievement as well as improve social relations skills, foster tolerance, and respect for other people's opinions.

2) The theoretical cooperative learning method can realize students' needs in learning to think creatively, solve problems, and integrate knowledge with experience.

The Student Teams Achievement Division (STAD) type of cooperative learning combines the use of lecture, question and answer, and discussion models [12]. This form of cooperative learning is that students are placed in study groups of four or five students who are a mixture of different academic abilities. In each group, some students have high, medium, low achievement or variations in gender, racial, and ethnic groups or other social groups [11]. In line with that, STAD type cooperative learning is a learning system that provides opportunities for students to work together with fellow students in structured tasks. In this system, the teacher acts as a facilitator [13].

\section{METHODOLOGY}

This research is quasi-experimental because not all variables that appear in experimental conditions can be strictly regulated and controlled. In this study, there are two sample classes, namely the pretest class and the posttest class. The pretest class is a class in the even semester 2018/2019, totalling 23 people, and the posttest class is a class in the even semester 2019/2020 totalling 24 people. The instrument used to collect data in this study was a questionnaire. In this research, there were four questionnaire indicators filled out by students, namely (1) attitudes and character indicators,

(2) improved presentation and discussion performance,

(3) students' views on the final project on making UNAND sustainability reports, and (4) Assessment by a colleague. The questionnaire can be found in the Appendix.

The technique of analyzing the questionnaire was carried out in the following way. First, determine the questionnaire that has been processed, namely the questionnaire that meets the criteria set out in the questionnaire examination. Second, determine the alternative qualifications for each questionnaire item's answers using a Likert scale of 1 (very poor) to 5 (very good). Third, the questionnaire will be processed by transferring the qualitative questionnaire data into quantitative data based on the alternative questionnaire answer criteria, which are the respondents' choice of each questionnaire item. Fourth, establish a benchmark for the percentage calculation result category as a guideline for interpreting the data that has been obtained from the percentage calculation.

Furthermore, data analysis of this study's results uses the percentage method to see an increase in student learning outcomes in the Sustainability Accounting course. At the end of this article discusses the effect of using the STAD cooperative learning model on the learning outcomes of students in the Sustainability Accounting course.

\section{RESEARCH RESULT}

4.1 Distribution of Final Values Before and After using the Cooperative Model Type STAD

The number of students involved in this study was 47 people consisting of 2 student groups, namely 23 students in the even semester 2018/2019 and 24 students in the even semester 2018/2019. Table 1 shows the distribution of student scores in the two test groups.

Table 1: Distribution of Students' Grades

\begin{tabular}{|l|l|c|c|}
\hline No & $\begin{array}{c}\text { Distribution of } \\
\text { Grade }\end{array}$ & Group 1 & Group 2 \\
\hline 1 & A & 6 & 11 \\
\hline 2 & A- & 6 & 5 \\
\hline 3 & B+ & 5 & 6 \\
\hline 4 & B & 4 & 1 \\
\hline 5 & B- & 1 & 1 \\
\hline 6 & C+ & 0 & 0 \\
\hline 7 & C & 0 & 0 \\
\hline 8 & C- & 78.2 & 79.5 \\
\hline 9 & Average Score & & \\
\hline
\end{tabular}

As shown in table 1, in the first group, students who get A scores are six people, A-scores are six people, B + scores are five people, B values are four people, B-1 grades are, $\mathrm{C}+$ scores are one people. From the distribution of student scores in the first group, it can be seen that the learning methods and learning assessment are not optimal because there are still students who get $\mathrm{C}$ and $\mathrm{B}$ - scores. In the second group, 11 students got Agrade, $5 \mathrm{~A}$ - grades, $1 \mathrm{~B}$-grade, $6 \mathrm{~B}+$ grades, and $1 \mathrm{~B}-$ grade.

From these results, we can see that after the STAD type cooperative method was applied in the Sustainability Accounting course, students' final grades seemed to increase. Before the application of this method, the final score of students was still $\mathrm{C}$. Meanwhile, after the application of the method, the final score of students got the lowest score of B-.

\subsection{Student Responses To The Application Of The Cooperative Method Type STAD}

Student responses to the application of the learning model and the assessment system applied are seen from four indicators, namely (1) attitude and character indicators, (2) improvement in presentation and discussion performance, (3) giving group final assignments, (4) peer assessment. These results were obtained from a questionnaire distributed via google form online to students. The questionnaire can be found in Appendix 1. 


\subsubsection{Attitude and Character Indicators}

Students are asked to assess their attitude and character in the learning process in the Sustainability Accounting course. Table 2 shows their responses to the improvement and change in their attitudes.

Table 2: Assessment of Student Attitude Indicators

\begin{tabular}{|l|l|l|}
\hline No & Student Attitude & $\begin{array}{l}\text { Average } \\
\text { Score }\end{array}$ \\
\hline 1 & Increase Curiosity & 4.41 \\
\hline 2 & Learn Confidence & 4.50 \\
\hline 3 & Responsible Learning & 4.59 \\
\hline 4 & Discipline Learning & 4.55 \\
\hline 5 & Increase Accuracy & 4.23 \\
\hline 6 & $\begin{array}{l}\text { Increase the Sense of } \\
\text { Cooperation }\end{array}$ & 4.50 \\
\hline 7 & $\begin{array}{l}\text { Learn to Listen to } \\
\text { Explanations }\end{array}$ & 4.59 \\
\hline 8 & Increased Initiative Asking & 4.50 \\
\hline 9 & Answer Questions Clearly & 4.14 \\
\hline 10 & Responding to Problems & 4.41 \\
\hline & Overall average score & 4.44 \\
\hline
\end{tabular}

From table 2, it can be seen that the improvement of student attitudes and character with the STAD method is outstanding. Changes in attitude that are very prominent can be seen in the increase in responsibility and learning to listen to friends' explanations. The following is an additional explanation by students about other attitude changes after attending a sustainability accounting course.

a) Be more thorough and patient.

b) Explore more resources and knowledge related to the environment and social matters that are no less important than finance.

c) Be more punctual in attending lectures and submitting assignments.

d) Improve the quality of students in every class assignment and presentation.

e) Change in attitude that they feel, namely the totality of everything for maximum results.

f) Increase the concern about the non-financial impact of company activities.

g) Be able to work together as a team and be able to do a good analysis.

h) Be more active.

i) Increase self-confidence in expressing opinions and skills in analyzing company performance in the future of GRI.

j) Increase self-confidence and also increase good cooperation.

\subsubsection{Improved Performance of Presentations} and Discussions

Students are asked to provide an assessment of improving the performance of presentations and discussions in the learning process in the Sustainability
Accounting course. Table 3 shows their assessment of their improved performance in presentations and discussions.

Table 3: Assessment of Presentation and Discussion Performance

\begin{tabular}{|l|l|l|}
\hline No & $\begin{array}{l}\text { Presentation performance } \\
\text { indicators }\end{array}$ & $\begin{array}{l}\text { Average } \\
\text { Score }\end{array}$ \\
\hline 1 & $\begin{array}{l}\text { Ability to write papers with } \\
\text { precision }\end{array}$ & 4.18 \\
\hline 2 & $\begin{array}{l}\text { Ability to choose the right } \\
\text { presentation method }\end{array}$ & 4.36 \\
\hline 3 & $\begin{array}{l}\text { Ability to design presentation } \\
\text { media appropriately }\end{array}$ & 4.45 \\
\hline 4 & $\begin{array}{l}\text { Ability to select presentation } \\
\text { material correctly }\end{array}$ & 4.32 \\
\hline 5 & $\begin{array}{l}\text { Can understand presentation } \\
\text { ethics }\end{array}$ & 4.41 \\
\hline 6 & $\begin{array}{l}\text { Can Answer Questions } \\
\text { Correctly }\end{array}$ & 4.32 \\
\hline 7 & Studying Discussion Ethics & 4,41 \\
\hline & Overall average score & 4.34 \\
\hline
\end{tabular}

From table 3, it can be seen that the increase in student performance in presentations using the STAD method is outstanding. A very noticeable performance improvement can be seen in the ability to design presentation media appropriately. The following is an additional explanation by students about other performance improvements after attending a lecture on sustainability accounting using the STAD method.

a) Techniques in delivering material. When not face to face with participants.

b) Video Editing Skills.

c) Better understanding because the learning points are more precise in the discussion method.

d) Learn to use media and presentation support software properly.

e) We are getting new skills, especially in the field of editors.

f) Students can create and edit attractive ppt.

g) With this learning can improve the ability to analyze topics and make presentations objectively.

h) More problems were encountered.

i) Increased communication skills in answering audience questions, increasing insights related to the material being studied.

j) Understand how to write a correct paper and understand how to present and answer questions correctly.

\subsubsection{Assignment in Preparing Sustainability Report}

In this course, students are asked to assess their assignment in making Andalas University sustainability reports in the learning process in the Sustainability Accounting course. Table 4 shows their assessment of the assignment given to them in making Andalas University's sustainability reports as a group. 
Table 4: Assessment of Sustainability Report Preparation

\begin{tabular}{|l|l|l|}
\hline No & $\begin{array}{l}\text { Sustainability Report Making } \\
\text { Assessment Indicators }\end{array}$ & $\begin{array}{l}\text { Average } \\
\text { Score }\end{array}$ \\
\hline \hline 1 & $\begin{array}{l}\text { Increased understanding of the } \\
\text { task given. }\end{array}$ & 4.64 \\
\hline 2 & $\begin{array}{l}\text { Understand the importance of } \\
\text { argumentation in completing } \\
\text { tasks }\end{array}$ & 4.55 \\
\hline 3 & $\begin{array}{l}\text { Learning to compile a } \\
\text { complete report }\end{array}$ & 4.50 \\
\hline 4 & $\begin{array}{l}\text { Learning to write reports } \\
\text { according to standards }\end{array}$ & 4.41 \\
\hline 5 & $\begin{array}{l}\text { Learning to make reports that } \\
\text { are easy to understand }\end{array}$ & 4.32 \\
\hline 6 & $\begin{array}{l}\text { Learning the importance of } \\
\text { accurate data }\end{array}$ & 4.45 \\
\hline 7 & $\begin{array}{l}\text { Learning about the importance } \\
\text { of adequate data }\end{array}$ & 4.45 \\
\hline 8 & $\begin{array}{l}\text { Learning about the selection } \\
\text { of important topics }\end{array}$ & 4.41 \\
\hline 9 & $\begin{array}{l}\text { Learning to make } \\
\text { presentations via video }\end{array}$ & 4.41 \\
\hline & Overall Average Score & $\mathbf{4 . 4 6}$ \\
\hline
\end{tabular}

Other lessons learned in preparing the Sustainability Report in groups are as follows.

a) Better understand the needs of the company and the company environment through sustainability reports.

b) Increase creativity.

c) Able to hone creativity and be creative in making SR.

d) Be able to know and make a sustainability report following the applicable GRI and can express creativity in designing the report.

e) Data is the key to report preparation, while creativity is the key to delivering information from the report.

f) Become interested in video editing.

g) That is the importance of understanding the report's design because a sustainability report will be interesting if it has an attractive design. So that encourages us to learn to use design applications.

h) Increase Creativity.

i) Increase responsibility for the surrounding environment and able to improve skills in video making.

j) Become more familiar with the contents of the sustainability report.

k) Gain skills and experience in preparing sustainability reports.

1) It can provide more knowledge about the correct sustainability report, make a report according to existing regulations, and understand the suitable media to be used in presenting the report.

\subsubsection{Peer Assessment}

Based on the group assignment asked each group to make about Andalas University Sustainability Report, students were asked to give scores on other groups' reports. The questionnaires are prepared for the students to be filled in by using google form. The questionnaire can be found in Appendix 2. The following are their comments on the assignment to provide peer ratings:

a) Feeling appreciated by the lecturer

b) can increase self-commitment

c) have the ability to judge in the best way,

d) can reduce the attitude of resistance to feedback,

e) can increase self-achievement

f) can encourage great motivation to learn

g) build a positive learning attitude,

h) increase self-confidence

i) Increase honesty

j) Increase mutual respect

k) increase the occurrence of social interactions

1) can focus on the learning process

m) be aware of one's strengths and weaknesses

n) Comparing the abilities of each so that it can be motivated to explore their own potential

o) Train the ability to make fair and wise decisions

p) Can learn new things from peer videos

q) Learn to be an objective person in judging

r) Can foster trust in everything that is done and be responsible for what has been done

s) Because those who judge friends, we must adapt to the millennial era, especially in making videos.

t) Provide mutual support between peers

u) We can provide feedback on innovations made by friends and can also increase knowledge and make ourselves more creative

v) Provide mutual support between peers

\section{DISCUSSION}

Data testing results indicate that the learning outcomes of students using the STAD cooperative model are better than those using the discussion method. The scores obtained by students in the posttest class were higher than the scores obtained by students in the pretest class. Learning using the STAD cooperative model emphasizes cooperation between students in groups to achieve common goals. This type of STAD cooperative learning can provide opportunities for students to be directly involved in the teaching and learning process and use all their potential to develop student abilities. Students are given the opportunity to collaborate and elaborate with peers in group discussions to solve a problem at hand.

The STAD type cooperative model is very appropriate for students in sustainability accounting courses. It is evident from the increased learning outcomes of students taught using this model. In line with that, there was an increase in student learning outcomes after applying the STAD type cooperative learning model [14]. It had a significant increase, namely $53.85 \%$, learning completeness in cycle 1 to $90.38 \%$ learning completeness in cycle 2. Consistent with the previous research, the application of the STAD type cooperative learning model can improve student learning outcomes in the Mathematics 2 course, which is marked by an increase in the average learning 
outcomes of Mathematics 2 in each cycle [15].. Furthermore, the STAD type cooperative learning model has been proven and can improve student mathematics learning outcomes [16].

From some of the research results above, it can be concluded that the cooperative model type STAD is very influential on student learning outcomes. By applying this model, students will increasingly understand the material and be creative in completing assignments assigned by the lecturers. In addition, the STAD-type cooperative model can also improve student motivation and communication skills. A learning metthod using the STAD learning model combined with RQA based on Lesson study could increase the learning motivation and communication skills of students of the 2013 Biology Education in Biology Study Program by 55\% [17].. Besides, the increase in students' communication skills from cycle I to cycle II was $8.21 \%$. Furthermore, the STAD type cooperative model proved significantly in increasing student competence in filling partographs [18]. The skills of Indragiri Rengat's Midwifery Academy showed a very significant improvement after using the STAD cooperative learning model.

Based on the explanation of previous research results, the cooperative model type STAD influences learning outcomes, learning motivation, student communication, and student partograph filling skills. That is, this model does not only affect one ability but many other abilities. The STAD type cooperative model can not only be used in sustainable accounting courses but for other courses, it is also very suitable to be applied.

\section{CONCLUSION}

The results showed an increase in student learning outcomes if the teaching and learning implement cooperative model type STAD. Based on student learning outcomes, the following increases in learning outcomes after implementing cooperative model type STAD in Sustainability Accounting Class. First, students experienced increasing their attitude and character after having class. Second, They can improve their ability in presentation and discussion performance. Third, by having a group assignment, their ability and experience of working in groups increased. Finally, they feel satisfied with their marks because of involving them in the implementation of peer reviews in the marking process. The study's findings indicate that the application of the STAD type cooperative method can increase student grades. This study's results are expected to be used as a guide for the implementation of other courses to increase students' understanding of the subjects they are studying. Based on the study results, it can be concluded that using the STAD type cooperative learning method in the Sustainability Accounting course can improve student learning outcomes.

\section{ACKNOWLEDGMENT}

This work was supported by Lembaga Pengembangan Pendidikan dan Penjaminan Mutu Universitas Andalas year 2020 research Grant. The contract number is No.T.06/UN.16.18/PT.01.03/2020.

\section{REFERENCES}

[1] Sitepu, B.P \& Lestari, I. (2018). Pelaksanaan rencana pembelajaran semester dalam proses pembelajaran di perguruan tinggi perspektif. Ilmu Pendidikan, 32 (1), 43-53. DOI: https://media.neliti.com/media/publications/25 9456 pelaksanaan-rencana-pembelajaransemeste- 3684f79d.pdf.

[2] Kemenristekdikti. (2015). Peraturan kementerian riset, teknologi, dan pendidikan tinggi republik Indonesia Nomor 44 Tahun 2015 tentang standar nasional pendidikan tinggi. Jakarta: Kementrian Riset, Teknologi, Dan Pendidikan Tinggi.

[3] Brundtland Report. (1987). Our common future. Oxford University Press, Oxford.

[4] Isjoni. (2010). Pembelajaran kooperatif meningkatkan kecerdasan komunikasi antar peserta didik. Yogyakarta: Pustaka Pelajar.

[5] Istarani \& Muhammad Ridwan. (2014). 50 tipe pembelajaran kooperatif. Medan: Media Persada.

[6] Widyaningsih. (2015). Penerapan pembelajaran listrik dinamis model kooperatif tipe STAD menggunakan pendekatan CTL dengan integrasi nilai-nilai karakter terhadap aktivitas dan hasil belajar peserta didik. Jurnal Pancaran, 4(2),223- 234.

[7] Rusman. 2017. Belajar dan pembelajaran.Jakarta: Kencana.

[8] Thobroni. 2017. Belajar dan pembelajaran. Yogyakarta: Ar-Ruzz Media.

[9] Hutagaol, J. (2012). Strategi meningkatkan kepatuhan wajib pajak. Diakses melalui http://www.pajak.go.id/content/strategimeningkatkankepatuhan-wajib-pajak pada September 2020.

[10] Lako, A. (2010). Dekonstruksi CSR dan reformasi paradigma bisnis dan akuntansi. Jakarta: Erlangga.

[11] Slavin, Robert E. 2005. Cooperative learning teori, riset dan praktik (diterjemahkan oleh Narlita Yusron). Bandung: Nusa Media.

[12] Sani, Ridwan Abdullah. 2019. Strategi belajar mengajar. Depok: Rajawali Press.

[13] Lie, Anita. (2010). Mempraktikkan cooperative learning di ruang-ruang kelas. Jakarta: Grasindo.

[14] Yanthi, M.D. (2017). Penerapan model pembelajaran kooperatif tipe Student Teams Achievement Division (STAD) untuk meningkatkan hasil belajar mahasiswa pada mata kuliah sistem informasi akuntansi. Dinamika Penelitian: Media Komunikasi Sosial Keagamaan. 17 (2), 199-219.

[15] Narpila \& Dahlya, S .(2017). Pembelajaran kooperatif tipe STAD untuk meningkatkan 
hasil belajar matematika 2 mahasiswa teknik informatika Universitas Potensi Utama. Seminar Nasional Matematika (SEMNASTIKA), Medan.

[16] Sunita, N.W. (2017). Pengaruh model pembelajaran kooperatif tipe STAD terhadap

[17] Tendrita, M. \& Sari, A. P. P. (2020). Penerapan model pembelajaran kooperatif tipe Student Team Achievement Divisions (STAD) dipadu RQA berbasis lesson study untuk meningkatkan motivasi belajar dan kemampuan komunikasi mahasiswa pendidikan biologi universitas negeri malang. Jurnal Bioedusiana, 5 (1), 1-13. hasil belajar matematika ditinjau dari minat belajar. Jurnal Emasains, 6 (2), 169-179.

[18] Yulizawati1 \& Rismawanti, V. (2015). Pengaruh model pembelajaran kooperatif tipe STAD terhadap keterampilan pengisian partograf mahasiswa kebidanan, Journalaipkind.or.id, 1 (1), 39-42.

Appendix 1: Student evaluation toward implementation of STAD type cooperative learning method

For the following indicators, please choose the rate based on your experiences in Sustainability Accounting Class.

A. INDICATORS OF ATTITUDE AND CHARACTER

\begin{tabular}{|l|l|l|l|l|l|l|}
\hline No. & Attitude Indicator & \multicolumn{3}{|l|}{ Scores } & $\mathbf{4}$ & $\mathbf{5}$ \\
\hline & & $\mathbf{1}$ & $\mathbf{2}$ & $\mathbf{3}$ & $\mathbf{4}$ & \\
\hline $\mathbf{1}$ & Increase Curiosity & & & & & \\
\hline $\mathbf{2}$ & Learn Confidence & & & & & \\
\hline $\mathbf{3}$ & Responsible Learning & & & & & \\
\hline $\mathbf{4}$ & Discipline Learning & & & & & \\
\hline $\mathbf{5}$ & Increase Accuracy & & & & & \\
\hline $\mathbf{6}$ & Increase the Sense of Cooperation & & & & & \\
\hline $\mathbf{7}$ & Learn to Listen to Explanations & & & & & \\
\hline $\mathbf{8}$ & Increased Initiative Asking & & & & & \\
\hline $\mathbf{9}$ & Answer Questions Clearly & & & & & \\
\hline $\mathbf{1 0}$ & Responding to Problems & & & \\
\hline
\end{tabular}

Other experiences related to improvement in attitude and character:

B. IMPROVEMENT OF PRESENTATION AND DISCUSSION PERFORMANCE

\begin{tabular}{|c|c|c|c|c|c|c|}
\hline No. & Presentation performance indicators & \multicolumn{5}{|c|}{ Scores } \\
\hline 1 & Ability to write papers with precision & 1 & 2 & 3 & 4 & 5 \\
\hline 2 & Ability to choose the right presentation method & & & & & \\
\hline 3 & Ability to design presentation media appropriately & & & & & \\
\hline 4 & The ability to select presentation materials correctly. & & & & & \\
\hline 5 & Can understand presentation ethics & & & & & \\
\hline 6 & Can Answer Questions Correctly & & & & & \\
\hline 7 & Studying Discussion Ethics & & & & & \\
\hline
\end{tabular}

Other lessons learned in assigning Papers presentations:

\section{MAKING A UNAND SUSTAINABILITY REPORT}

\begin{tabular}{|c|c|c|c|c|c|c|}
\hline No. & Sustainability Report Making Assessment Indicators & \multicolumn{5}{|c|}{ Scores } \\
\hline 1 & Increased understanding of the task given & 1 & 2 & 3 & 4 & 5 \\
\hline 2 & Understand the importance of argumentation in completing tasks & & & & & \\
\hline 3 & Learning to compile a complete report & & & & & \\
\hline 4 & Learning to write reports according to standards & & & & & \\
\hline 5 & Learning to make reports that are easy to understand & & & & & \\
\hline 6 & Learning the importance of accurate data needs & & & & & \\
\hline 7 & Learning about the importance of adequate data & & & & & \\
\hline 8 & Learning about the selection of important topics & & & & & \\
\hline 9 & Learning to make presentations via video & & & & & \\
\hline
\end{tabular}

Other lessons learned in preparing a Sustainability Report:

D. Give your positive comments on the implementation of peer Assessment:

E. Give your input on future corrective actions for the overall implementation of this lecture 
Appendix 2: Peer Review toward Group Project

Email address:

Group Name Assessed:

Names of the group members:

Standards Used for Reports:

- Standard 100

- Standard 200

- Standard 300

- Standard 400

\begin{tabular}{|c|c|c|c|c|c|}
\hline \multirow[t]{2}{*}{ No. } & \multirow[t]{2}{*}{ Attitude Indicator } & \multicolumn{4}{|c|}{ Scores } \\
\hline & & 1 & 2 & 3 & 4 \\
\hline 1 & Creativity in Selection of Report Themes & & & & \\
\hline 2 & Reported Standard Completeness* & & & & \\
\hline 3 & Creativity in using photos in the report* & & & & \\
\hline 4 & Explanation of each standard in the report & & & & \\
\hline 5 & Creative use of words in the report* & & & & \\
\hline 6 & Creativity in Using Images on Video* & & & & \\
\hline 7 & The creativity of Video Presentation Methods* & & & & \\
\hline
\end{tabular}

Evaluator:

Matrix Number:

Evaluator Name: 